\title{
20. Yüzyıl Başlarında Feriköy’deki Vakıf Arazilerinin Dönüştürülmesi
}

\author{
Ali ŞENYURT ${ }^{1 *}$
}

\section{ÖZ}

Beyoğlu ve Şişli ilçelerinin arasında kalan Feriköy semtinin gelişimi 19. yüzyılın sonlarına rastlamaktadır. Ayrıca, Feriköy'ün İstanbullu Rumların mesken tuttuğu Tatavla (Kurtuluş) semti ile komşu olmasına rağmen ikamet alanı olarak rağbet görmemesi dikkat çeker. Tanzimat Fermanı'nın ardından yapılan bir dizi hukuki düzenlemelerden biri olan toprak hukukundaki değişiklikler semtin geleceğini şekillendirmiştir. Böylece, Feriköy'e bir yandan Balkanlar'da toprağını kaybedip gelen muhacirlerin, diğer yandan Beyoğlu'na artan rağbet nedeniyle yerleşim imkanı bulamayan yabancıların ve Osmanlı tebasından gayrimüslimlerin ikamet ettirildikleri görülmektedir. Meydana gelen gelişmeler idare açısından çözüm bekleyen birçok sorunu üretmiştir. Yeni yerleşim alanları için yol, su gibi ihtiyaçların temininin yanında okul ve karakol inşa etmek de idarenin görevleri arasındadır. Söz konusu faaliyetlerin sürdürülebilir kılınması açısından vakıflara ait mülklerin dönüştürülerek özel mülkiyete açılması gerekmiştir. Niteliği itibariyle şahıs vakıflarının dönüştürülmesi mümkün olmadığından sultan vakıflarına ait arazilerin (gayrısahih vakıf arazi) bu amaçla kullanıldığı anlaşılmaktadır. Başbakanlık Osmanlı Arşivi belgeleri; Feriköy semtinde Sultan Bayezid-i Veli vakfına ait arazilerin bu şekilde dönüştürülerek kullanıldığını desteklemektedir. Bu bakış açısıyla makalede, Feriköy'deki vakıf arazilerinin el değiştirme süreci bazı belgeler ışığında değerlendirilmiştir.

Anahtar Kelimeler: Feriköy, Osmanlı Toprak Hukuku, Vakıf Arazilerinin Dönüştürülmesi, Sultan Vakıfları.

\section{Conversion of Foundation Lands in Feriköy in the Early 20th Century}

\begin{abstract}
The development of the Feriköy town between the districts of Beyoğlu and Şişli, is found in the late 19th century. Moreover, although Feriköy is adjacent to the Tatavla (Kurtuluş) neighbourhood, which the Greek residents of Istanbul live in, it attracts attention that it is not popular as a residence area. Changes in territorial law, one of a number of legal arrangements made after the Imperial Edict of Gülhane, have shaped the future of the district. Thus, it is seen that on the one hand the immigrants who lost their land in the Balkans and on the other hand the non-resident foreigners who could not find a settlement due to the increasing demand of Beyoğlu and the non-Muslims were resident in Feriköy. The going-on developments produced many problems waiting to be solved in terms of administration. For the new settlement areas, it is also among the tasks of the administration to build schools and police stations as well as the provision of roads and water needs. In order to make these activities sustainable, it is necessary to convert the properties belonging to the foundations and make them be open to private property. Since it is not possible to transform individual foundations by nature, it is understood that the land belonging to the sultan foundations (inaccurate foundation land) is used for this purpose. Documents of the Prime Ministry Ottoman Archives support that in Feriköy district, Sultan Bayezid-i Veli foundation's lands have been transformed and used in this way. From this point of view, the process of change of foundation lands in Feriköy has been evaluated in the light of some documents.
\end{abstract}

Key Words: Feriköy, Ottoman Real Property Law, Conversion of Foundation Lands, Sultan Foundations

\footnotetext{
${ }^{1}$ Dr. İktisat Bölümü, al.senyurt@gmail.com

*ilgili yazar / Corresponding author: Ali ŞENYURT, al.senyurt@gmail.com

Gönderim tarihi: 10.05.2017

Kabul tarihi: 30.05.2017
} 


\section{GíRiş}

Osmanlı Devleti'nin sosyo-kültürel gelişimine öncülük etmiş vakıflar açısından 19. yüzyıldaki bazı tarihler önemli kırılma noktalarını oluşturmaktadır. 1839 Tanzimat Fermanı, 1856 Islahat Fermanı ve 1858 tarihli Kanunname-i Arazi, doğrudan veya dolaylı olarak yarattığı etkiler bakımından o döneme kadar büyük bir özenle muhafaza edilmiş vakıfların dağılma sürecine girişini hızlandıran başlıca olaylar olarak kabul edilebilir. Özellikle 19. yüzyılın sonlarına doğru Osmanlı topraklarında yabancılara da emlâk ve arazi tasarrufu imkanının sağlanması vakıflara ait birçok mülkün şu veya bu sebeple elden çıkmasına yol açmıştır. Bu gelişmeler çözüm bekleyen birçok sorunu üretmiştir. İdare bir yandan bunlarla başetmeye çalışırken diğer yandan kaybedilen topraklardan gelen muhacirler için yeni yerleşim alanlarının yaratılması amacıyla başvurulan kaynak yine vakıflara ait araziler olmuştur. Başkent İstanbul özelinde konu değerlendirildiğinde artan nüfus ile birlikte kentin büyümesi alt ve üst yapı intiyaçları için bazı değişimlerin yaşanmasını zorunlu hale getirmiştir. Arşiv belgelerinin incelenmesi sırasında bahsedilen bu değişimin ve dönüşümün yaşandığı yerlerden birinin Feriköy olduğu belirlenmiştir. Makale, Feriköy'deki vakıf arazilerinin el değiştirmesini konu ile ilgili tespit edilen belgeler ışığında incelemeyi amaçlamaktadır. ${ }^{2}$

\section{OSMANLI DÖNEMINDE FERIKÖY SEMTININ KISA TARIHÇESI}

Doğu ve güneydoğusunda Kurtuluş, güneyinde Eskişehir ve Yenişehir mahalleleriyle Dolapdere, batısında Feriköy Mezarlığı, kuzeybatısında Baruthane Deresi Yolu ve Piyale Paşa Bulvarı'nın bulunduğu Feriköy Semti, batı ve güney yönlerinde Tatavla (Kurtuluş) sırtlarının eteklerinde yer almaktadır. Semtin, asıl Feriköy Mahallesi'ni meydana getiren güney bölümünün, 16. yy'da buradaki bir kiliseye atfen Aya Dimitri adını aldığı; doğusundaki Kurtuluş'un Tatavla diye adlandırıldığı; buraların 19. yy'ın ortalarına kadar üzerinde yer yer küçük Rum köyleri bulunan boş arazi olduğu bilinmektedir (D.B.İ.A., 1994, s. 293). 18. yy'da İstanbul'un bu bölgesinde, gelişme ekseni dışında kalan tek yerleşim birimi, Hagios Dometrios (Aya Dimitri) tepeleri üzerinde kurulu olan Tatavla (Kurtuluş) köyü olmuştur. 1874 yılında İstanbul'a gelen İtalyan yazar ve gezgin Edmondo De Amicis, gezi anılarını topladığı Constantinopoli adlı eserinde; Aya Dimitri mahallesine ulaşabilmek için Pangaltı tepesinden inildiğini, kurumuş küçük bir dere yatağını geçtikten sonra bir başka tepeye tırmanılması gerektiğini anlatmaktadır. (Ş.R., 1987, s. 26, 27). Feriköy'ün İstanbullu Rumların mesken tuttuğu Tatavla (Kurtuluş) semti ile komşu olmasına rağmen ikamet alanı olarak rağbet görmemesi dikkat çeker. Reşad Ekrem Koçu; yakın geçmişe kadar oba çingenelerinin bu semtin kırlığında çadır kurduğundan bahsetmektedir (Koçu, 1971, s. 5684). Semtin adının nereden geldiği de ayrı bir tartışma konusudur. Osmanlıca "fer'î" sözcüğünden gelebileceği düşünülse de, 1880 başlarına ait 1301 İstatistik Cetveli'nde "Feriköy Mahallesi" olarak geçmektedir. 1909'da ise mahalleden "Feri Kariyesi" diye söz edildiği görülmektedir. ${ }^{3}$ Sözcüğün bu şekilde yazım biçimi, teyit edilmemiş olmakla birlikte konu hakkındaki bir rivayetin gerçek olduğu yönündeki kanıları güçlendirmektedir. Buna göre, semtin adı Abdülmecid veya Abdülaziz döneminde

\footnotetext{
${ }^{2}$ Bu çalışmaya verdiği burs ile destek olan VAKAR'a ve bilim kurulu başkanı değerli hocam Prof.Dr. Ahmet Kal'a'ya teşekkür ederim.

${ }^{3}$ Arşiv kayıtları üzerinde yaptığımız incelemelerde 1909 tarihine ait bir belgede semtten "Feri Karyesi” olarak bahsedildiği belirlenmiştir. DH.MKT., 2876/77 no.lu bu belgeye ilerleyen bölümlerde daha detaylı olarak değinilecektir. Ancak arşiv belgelerinde bu semtte mahalle oluşturulması ile ilgili çalışmaların daha geç tarihlerde başladığı belirlenmiş olmasına karşın 1880 'lerdeki İstatistik Cetveli'nde “Feriköy Mahallesi” ibaresinin yer aldığı görülmektedir.
} 
yaşamış Madam Feri'nin sonradan ölen kocasına padişah tarafından bölgedeki geniş arazilerin bağışlanmış olmasından kaynaklanmaktadır. Diğer bir ifadeyle semtin adı Madam Feri'den gelmektedir (Dünden Bugüne İstanbul Ansiklopedisi, 1994, s. 293). Ancak belirtildiği gibi tartışmalı olan bu husus bugüne kadar tam olarak doğrulanamamıştır. Türkiye Sigortacılar Daire-i Merkeziyesi adına topograf mühendis Jacques Pervititch tarafından 1922-1945 yılları arasında hazırlanan haritalarda Feriköy semtinin yer aldığı görülmektedir (Harita 1).

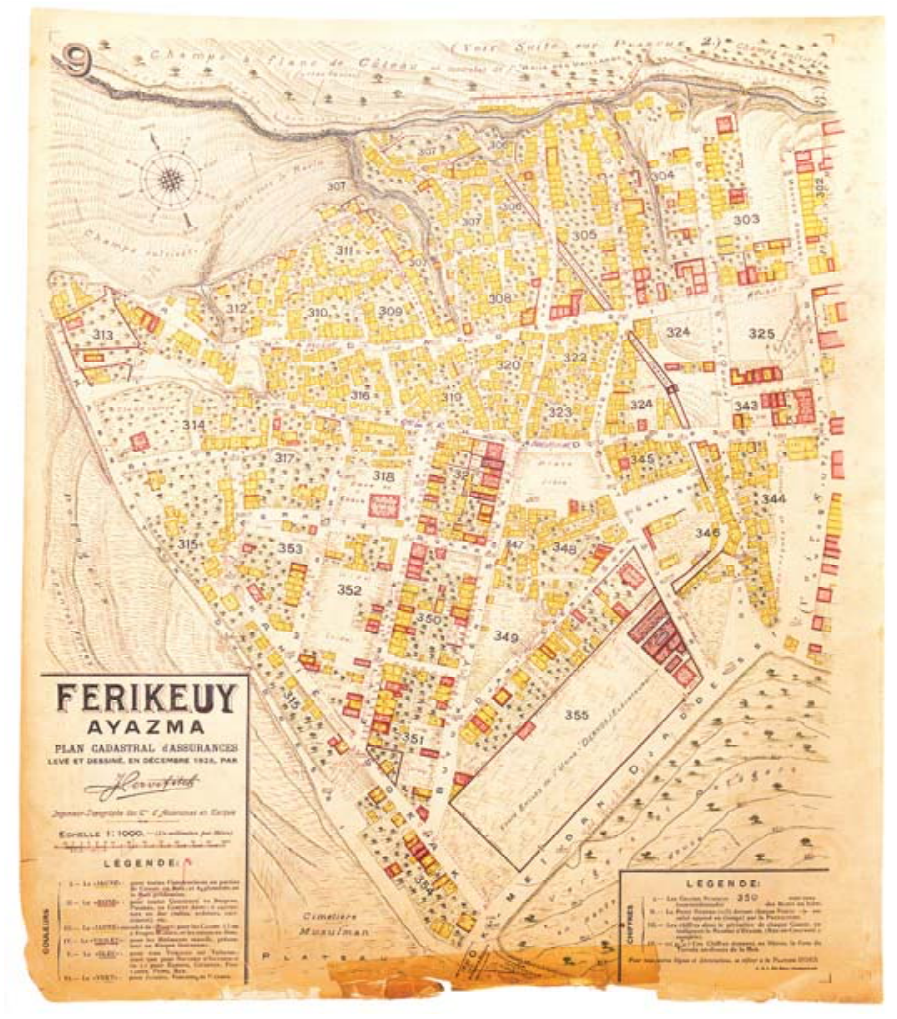

Harita 1: Pervititch Haritasında Feriköy

Öteden beri Rumların ve Ermenilerin ağırlıkta olduğu bir azınlık semti olan Feriköy'de 1870'lerde küçük bir baruthanenin, 1900'ün başlarında ise bir feshanenin bulunduğu bilinmektedir. ${ }^{4}$ 20. yüzyılın ilk çeyreğinde semtte Ermeni nüfus çoğalmaya başlamış, zamanla Rumların sayısı azalırken yerlerini Türkler ve Ermeniler almıştır (D.B.I.A., 1994, s. 293). Başbakanlık Osmanlı Arşivi belgelerinde; Feriköy'ün 19. yüzyılın sonlarına doğru dışarıdan gelen muhacirler için bir ikametgah alanı olarak değerlendirildiği tespit edilmiştir. Söz gelimi 26 Z 1309/22 Temmuz 1892 tarihli bir belgeden Romanya'nın Baban Dağı bölgesinden gelen 21 muhacirin Feriköy'e yerleştirildikleri görülmektedir (BOA, DH.MKT., Dosya no: 1975, Gömlek no: 43). Bu arada muhacirler için "Yeni Mahalle" adıyla bir mahalle oluşturulmasına karar verildiği anlaşılmaktadır (BOA, BEO., Dosya no: 1437, Gömlek no: 107762). Mahallenin teşekkülü ile ilgili çalışmalar 1900 yııının Şubat ayında başlatılmış olup, bu kapsamda imam ve muhtar mühürlerinin yaptırılması ve Nüfus İdaresi Siciline bildirilmesi istenmiştir (BOA, DH.MKT., Dosya no: 2308, Gömlek no:3). Mahalle imamlığına Hafız

\footnotetext{
${ }^{4} 1318$ (1900-1901) 'de özel teşebbüsle faaliyete geçen fes fabrikasının kimler tarafından kurulduğu ve ne kadar devam ettiği tespit edilememiştir. Faaliyetini sonlandırmasında Avusturya fesleri ile rekabete dayanamamasının etken olduğu tahmin edilmektedir. "Feriköy Fes Fabrikası" maddesi, Hüsnü Kınaylı, İstanbul Ansiklopedisi, s. 5686.
} 
Ebulhayr Efendi tayin edilmiştir (BOA, DH.MKT., Dosya no: 2272, Gömlek no:71). Ebulhayr Efendi'nin, aynı yılın Nisan ayında bu kez mahallenin ibtidai muallimliği görevini de yürütmesi uygun görülmüştür. Konu ile ilgili belgedeki ifadelerden daha öncesinde Feriköy ismiyle bir mahalle oluşturulmasına sıcak bakılmadığı ve dolayısıyla resmiyet kazanmadığı, ancak sonrasında Feriköy Yeni Mahalle ismine onay verildiği ortaya çıkmışıı. Karar değişikliğinin nedeni tam olarak anlaşılamamakla birlikte idarenin nüfus ve iskan politikaları ile ilgili olduğu tahmin edilmektedir (BOA, MF.MKT., Dosya no: 498, Gömlek no:50). 1934 tarihli Belediye Şehir Rehberi'nde Yenimahalle'nin Feriköy Mahallesi (pafta 18/154) sınırları içerisinde yer almadığı belirlenmiş olup, bu mahallenin Beyoğlu ilçesindeki Yenişehir isimli bölge olduğu veya Yeni Mahalle isminden vazgeçilerek tekrar Feriköy Mahallesi isminin kullanıldığı, düşünülmektedir. Öte yandan muhacirlerle birlikte bölge nüfusundaki artış idarecileri yeni tedbirler almaya yöneltmiştir. Bu kapsamda 1911 yılında Feriköy ve Şişli'nin büyüklükleri ile orantılı üç mahalleye ayrılması gündeme gelmiştir (BOA, DH.iD., Dosya no: 92-2, Gömlek no: 6). Feriköy’de yaşanan bu gelişmeleri anlayabilmek için, Osmanlı toprak hukukunun 19. yüzyılda yaşadığı dönüşümü incelemek faydalı olacaktır.

\section{19. YÜZYILDA TOPRAK HUKUKUNDA YAPILAN BAZI DÜZENLEMELER}

Osmanlı Devleti'nde önce askerlik alanında başlayan yenilik hareketleri şiddetli reaksiyonlarla karşılaşmış, III. Selim'in ölümüyle birlikte kesintiye uğramışsa da II. Mahmut döneminde tekrar canlanmış, 1826'da Yeniçeri Ocağı'nın kaldırılmasıyla askeri alandaki reform çalışmalarına devam edilmiştir. 1839'da Abdülmecid'in tahta çıkmasından kısa bir süre sonra okunan Gülhane Hatt-ı Hümayunu, Tanzimat Dönemi olarak adlandırılan yeni bir sürecin başlangıcı olmuştur. Bu süreçte adli ve idari alanda birçok değişiklikler yapılmış, hukuk sisteminde Avrupa kanunlarından esinlenerek yeni düzenlemeler getirilmiştir. 28 Şubat 1856 tarihinde, daha çok dış etkiler altında yayımlanan Islahat Fermanı ise hukuk açısından Tanzimat Fermanı'nın tamamlayıcısı olmuştur (Onar, 1985, s. 581, 589).

19. yüzyılda yapılan düzenlemelerden biri de toprak hukuku alanındadır. Kısa ve tasarımcı bir talimat olduğu görülen 1840 Nizamnâmesinin ardından 1858 Arazi Kanunnâmesi, 1859 Tapu Nizamnâmesi ve 1864 Vilayet Kanunu bu dönemin önemli uygulamaları olarak sayılabilir. Arazi Kanunnâmesi'nin giriş kısmında da belirtildiği üzere toprak, Memlûke (Mülk Arazi), Emirîyye (Mîrî Arazi), Mevkûfe (Vakıf Arazi), Metrûke (Metruk Arazi) ve Mevât (Ölü Arazi) olmak üzere beş sınıfa ayrılmaktadır (Mundy ve Smith, 2013, s. 78, 79). Bunlardan vakıf arazileri; aslı mülk olup da şahıslar tarafından vakfedilen araziler sahih vakıf, devlet arazisi olup sultan tarafından vakfedilen arazi ise gayrısahih vakıf arazi olarak isimlendirilmektedir. Sultan vakıflarına gayrisahih denilmesi vakfedilen arazinin mülk sayılmamasından kaynaklanmaktadır. Tahsis kabilinden vakıf veya irsâdî vakıf olarak da bilinen bu vakıflarda sultan devlete ait (mîrî) araziyi; sağlık, eğitim, bayındırlık gibi kamu hizmetlerinin yerine getirilmesi veya kamu hizmeti görüp de beytümâlden hakkı bulunanların maaşlarının karşılanması amacıyla rakabesi (mülk sahipliği) devlette kalmak ve gelirleri bir hayır işinde kullanılmak şartıyla vakfetmektedir. Gerekli görülmesi halinde söz konusu tahsis hükümet tarafından iptal edilebilmektedir (Ekinci, 2008, s. 496). İslamiyetten bu yana devam eden vakıflar, sultanlar için de bir hayır işi ve ülkenin gelişimine katkı olarak görüldüğünden birçok vakıf eseri ortaya çıkmıştır. Her sultanın sancak ve köy olarak vakfiyelerine rastlamak da mümkündür. Bunlar tek tek vakıf defterlerinde (Kuyûdu Kadîme) kayıt altına alınmıştır. Söz gelimi Fatih Sultan Mehmet'in Kırk Kilise, Vize, Hasköy, Edirne, Hayrabolu, Çorlu, Ereğli, Silivri ve İstanbul'da vakfiyeleri olmuştur. 19. yüzyılın başlarında Evkafı Hümayun Nezareti oluşturulmuş ve 12 Rabiulevvel 1242 (m. 
14 Ekim 1826) tarihinde ilk nazır olarak Elhaç Yusuf Efendi tayin olmuştur (Tuncer, 1962, s. 91).

19. yüzyılda yapılan bir başka düzenleme Osmanlı tebasından olmayan yabancıların mülk edinme ve arazi tasarrufu konusundadır. Gerek 1858 tarihli Arazi Kanunnâmesi ve gerekse 1867 tarihli İntikal Kanunu'nda Osmanlı Devleti tebasından olan müslim ve gayrimüslimlerin ayırt etmeksizin miri arazide tasarrufu ve intikali konularında bir ayrım gözetilmeden düzenlemeler yapılmış olmasına karşın yabancı statüsünde olan kişilerin arazi tasarrufu ve mülk sahibi olmayacaklarına dair bir yasağın yürürlükte olduğu görülmektedir. Bu konu 1860 tarihinde İngiltere'den yapılması planlanan bir istikrazda gündeme gelmiş ve İngiliz hükümetinin "Devletin tasarrufunda bulunan araziye, Osmanlı tebasının tabi olduğu şartlar dahilinde yabancılara tasarruf hakkının tanınması" şeklinde ileri sürdüğü koşul kabul edilmeyerek istikraz için Paris'e başvurulmuştur. Yabancıların Osmanlı topraklarında mülk edinebilme hakkı 1869 yılında çıkartılan kanunla mümkün hale gelmiştir. Ancak bu kanunla yabancılara gayrimenkullerde tasarruf ve temellük hakkı tanınmasına karşın miras hakkı verilmemiştir. Şevket Pamuk, 1869'da yabancılara toprak edinme hakkı tanınmasının ardından İngilizlerin, İzmir'in iç bölgelerinde önemli miktarda toprak satın aldıklarını ve ihracata yönelik büyük çiftlikler işletmeye başladıklarını ifade etmektedir (Kenanoğlu, 2002, s. 138-140).

Osmanlı hukuk düzeni, aynı zamanda tüzel kişilere de kayden gayrimenkul edinme hakkı tanımadığından özellikle gayrimüslüm cemaatlere ait kurumların fiilen ellerinde bulundurdukları gayrimenkullerin tapuda, ya güvendikleri tanınmış bir şahıs (Nam-ı Müstear) ya da, tarihi veya dini şahıslar (Nam-ı Mevhum) adına kaydedildiği anlaşılmaktadır. Cemaatlerin bu yolu takip ederek önce şahıs adına alınmış bir arazi üzerinde hastane, okul, kilise inşa ettikleri veya cemaat mezarlığı oluşturdukları görülmektedir. Özellikle toprak hukukunda meydana gelen değişikliklerle birlikte 19 . yüzyılın sonlarına doğru bu faaliyetlerin arttığı söylenebilir. Georgi P. Kostandov'un eserinde; Ekzarh I. Yosif isimli bir kişinin Bulgar Cemaati adına hareket ederek şahsı adına satın aldığı araziler üzerinde sonradan cemaat yapılarının inşa edildiğini ortaya koyması, konu hakkında önemli ipuçları vermektedir. Söz gelimi; günümüzde Vakıflar Genel Müdürlüğü tarafından kiralanan Şişli, Darülaceze Caddesi'ndeki Türkiye Hastanesi'nin bulunduğu yerde, 1896 tarihinde Ekzarh I. Yosif adına satın alınan arsa üzerine 1897 yılında inşasına başlanan ve 1902 yılında tamamlanan "Evlogi Georgiev" Bulgar Hastanesi hizmet vermeye başlamıştır. Aynı şekilde Beyoğlu Bulgar Ortaokulu (1993 yılında yıkılmış) ile Şişli'deki Ekzarhane binası ile Sveti İvan Rilski Kilisesi'nin (günümüzde faaliyetine devam ediyor) bulunduğu yerler de Ekzarh I. Yosif tarafından satın alınmıştır. Feriköy semtindeki Bulgar Ortodoks Mezarlığı ve Sveti Dimitar Kilisesi'nin bulunduğu alanın da aynı şahıs tarafından 1912 yılında satın alındığı belirlenmiştir (Konstandov, 2011, s. 94-103). Bulgar cemaati ile ilgili bu bilgilerden yola çıkarak Osmanlı topraklarında yabancılara mülk edinme hakkının tanınmasının ardından İstanbul'da gayrimüslimlerin daha yoğun yaşadığı Beyoğlu, Şişli, Feriköy gibi semtlerde hastane, okul, ibadethane, mezarlık gibi sosyal alanların kümeleşerek yaygınlaştığını bir tespit olarak ortaya koymak mümkündür. Öte yandan Feriköy’ün, adı geçen diğer semtlere göre daha yeni bir yerleşim alanı olmasına karşın ülkenin o dönemde içinde bulunduğu koşullara bağlı olarak vakıf, cemaat, muhacir bileşkeleri içerisinde yaşanan gelişmeleri birincil kaynaklardan izlemek ve yorumlamak konunun önemini artırmaktadır.

\section{FERIKÖY’DEKI VAKIF ARAZILERININ DÖNÜŞTÜRÜLMESI}

Arşiv belgelerinden anlaşıldığı kadarıyla Feriköy'ün yer aldığı bölge 19. yüzyılın sonlarından başlayarak, bir yandan Balkan'lardaki Osmanlı topraklarının kaybedilmesi 
nedeniyle gelen muhacirlerin yerleştirildiği, diğer yandan Şişli ve Beyoğlu'na yakınlığının da etkisiyle gayri müslim nüfusun ikamet alanı olarak tercih ettiği bir bölge haline gelmiştir. Farklı kültürlerden ve inançlardan gelen bu insanların doğal olarak ibadethane, okul ve mezarlık gibi sosyal ihtiyaçlarının karşılanması zorunlu hale geldiğinden nüfus ve yerleşim yoğunluğu giderek artmıştır. Demografik yapının bu yönde gelişim göstermesinde yukarıda değinildiği üzere Osmanlı toprak hukukunda yabancılar lehine yapılan düzenlemelerin de büyük etkisi olmuştur.

Toprak hukukunda yapılan bu değişiklikler yabancı bir ülke tebasından olan bir kişinin sahibi olduğu bir taşınmazı vererek bir başka taşınmazı alabilmesine diğer bir ifade ile değiştirebilmesine imkan sağlamıştır. Düzenleme vakıf mallarını da kapsamaktadır. Söz gelimi 16 Ca 1327/ 5 Haziran 1909 tarihli bir belgede; İngiliz vatandaşı Kirkor oğlu Malkon Gümüş Kirvan'ın Bahçekapı'ya yakın Şeyh Mehmed Geylânî Mahallesi'nde Yalı Köşkü Caddesi'nde bulunan bir vakıf arsanın Feriköy Ayazma'daki daha büyük bir arsa ile değiştirmek istediğine dair talebinin vakfa daha faydalı olacağı gerekçesi ile uygun görüldüğü, belirlenmiştir (BOA., BEO., Dosya no: 3566, Gömlek no: 267443).

"Ingiltere Devleti tebasından Kirgor veled-i Melkon Gümüş Kirvan'ın bahçesi kapısı kurbünde Şeyh Mehmed Geylânî Mahallesi'nde Yalı Köşkü Caddesi'nde taht-ı tasarrufunda bulunan dört yüz kırk bir zirâ' terbî‘ inde ve otuz beş bin küsur kuruş kıymetinde vakf arsanın Feriköyü'nde Ayazma Sokağı'nda mutasarrıf olduğu bin zirâ‘ terbî' inde ve yüz yirmi bin kuruş kıymetinde diğer bir kıt' a mülk arsa ile istibdâli vakfı hakkında enfa' idiği ber-nehc-i şer' î sâbit olduğu ve mülk arsanın senevî yüz yirmi kuruş icâre-i müecceleye tahammülü bulunduğu cihetle muamele-i istibdâliyenin icrası hususuna Şura-yı Devlet kararıyla bi'l-istizân irâde-i seniyye-i Cenâb-ı hilafet-penâhî şeref sudur buyurularak..."

Feriköy'deki vakıf arazilerinin dönüştürülme çalışmalarında zaman zaman oluşan tereddütlerde vakfiyeye dönme gereksinimi duyulmaktadır. 27 S 1328/ 10 Mart 1910 tarihine kayıtlı bir belgede; Feri Karyesi Sakız Ağacı'nda bulunan bir arsanın vakfiyetine ait fermanın bir suretinin Evkaf Mahkemesi'ne gönderilmesinin istendiğinden bahsedilmektedir (BOA, BEO., Dosya no: 3717, Gömlek no: 278709).

Öte yandan tespit edilen bazı arşiv belgeleri Feriköy'deki Sultan Beyazıd Han-ı Veli Vakfı'na ait vakıf mallarının kullanıma tahsis edildiğine işaret etmektedir. Örneğin, $26 \mathrm{C}$ 1327/ 15 Temmuz 1909 tarihli bir belgede, adı geçen vakfa ait sekiz bin elli bir zira büyüklüğündeki bir tarlanın değerinin binde onu tutarındaki kirasının Pangaltı'ndaki Rus Hastanesi'ne verilmesi kaydıyla Rusya Hükümeti adına kaydının düzetilmesinin uygun görüldüğü bildirilmektedir. 1909 yılına ait bu belgede semtin isminin "Beyoğlu'nda Feri Karyesi" olarak geçmiş olması dikkat çekicidir. Buna göre semtin "Yeni Mahalle" veya "Feriköy Mahallesi" yerine geçmişteki ismiyle yer alması konunun henüz netlik kazanmadığını göstermektedir (BOA., DH.MKT., Dosya no: 2876, Gömlek no:77).

"Beyoğlu'nda Feri Karyesi'nde caddede kain olup Sultan Bayezid Han-ı Veli hazretleri vakfına aid ve on dört numarada bulunan sekiz bin elli bir zira vüsatinde bir kıta tarlanın kıymet-i hâliyesinin binde onu icare-i zemine rabtı ile Pangaltı'da vaki Rus Hastahanesi'ne irad olmak üzre Rusya Hükümeti namına kaydının tashihi ve tebdilen sened itası hususuna Hariciye Nezareti makamından vuku bulan işar üzerine Şura-yı Devlet kararıyla..."

2 Za 1333/ 11 Eylül 1915 tarihli bir başka belgeden ise adı geçen vakfın Feriköy'de bulunan arsasının üzerine Ermeni Kilisesi'nin inşa edilmiş olduğu belirlenmiştir. Kilisede 
iki kapılı papaz odaları ile bir kömürlük de bulunmaktadır (BOA., MF.MKT., Dosya no: 1211, Gömlek no: 69).

"Irâde-i seniyye suretidir.

Feriköyü'nde Sultan Bayezid Han-ı sânî hazretleri vakfından bin sekiz yüz altmış dört metre terbîindeki arsa üzerine on dört metre tûl on metre arz altı metre irtifâ'ında ve sekiz pençere ve üç kapılı ve ahşap olark yapılmıs olan ve beş metre tûl ve on buçuk metre arz ve beş metre yirmi santimetre irtifâ' Inda ve on sekiz pençere ve iki kapıyı havi Papas odalarlyla dört metre yirmi santimetre tûl ve dokuz metre arz ve iki metre irtifâında bir kömürlük mahallini müştemil bulunan Ermeni Kilisesi mezkur kilisenin..."

Belgenin devamında, kilise bahçesinin bitişiğindeki Çoban sokağında ressam Meremmetciyân Zenob Efendi'ye ait arsa üzerindeki yirmi dört pencereli ve iki kapılı okulun (belgedeki ifadeden okulun kiliseye ait olduğu sonucu çıkarılmıştır) birikmiş vergilerinin tamamen tahsil edildiği belirtilmektedir. Ayrıca kilise ve okul için bundan böyle bulundukları mahallenin değerinin binde onu oranında bir ödemenin vakıf adına alınması kararlaştırılmıştır.

“...mezkur kilisenin bahçesi ittisâlinde ve çoban sokağında vaki ressam Meremmetciyân Zenob Efendi uhdesinde mukayyed beş yüz yirmi zira vüs'atinde bir arsa üzerine tûlen on sekiz ve arzan on irtifâ'an on iki buçuk zira ebâdında ve yirmi dört pençere ile iki kapıyı muhtevi kargir mektebin mebnî bulundukları mahalle kıymet-i hâzırasının binde onu nisbetinde vakfı namına mukataa-i zemin tahsis ve bu tarihe kadar yalnız mezkur mekteb binasının müterâkim vergileri tamamen tahsil ve mekteb hakkında Maarif-i Umumiye Nizamnamesi'nin yüz yirmi dokuzuncu maddesi ahkamına riayet olunmak üzre tasdik-i mevcudiyetleri Şura-yı Devlet kararıyla tensib edilmişdir."

Sultan Beyazıd Han-ı Veli Vakfı'na ait Feriköy Sakız Ağacı'ndaki tarlalardan mahalle oluşturulması düşünüldüğünden söz konusu tarlalardan 1200 arşınlık kısmının okul yapılabilmesi amacıyla tahsis edilmesine ilişkin bir karar $1 \mathrm{Ra}$ 1315/ 31 Temmuz 1897 tarihli belgede yer almaktadır (BOA, MF.MKT., Dosya no: 362, Gömlek no: 48).

"Sultan Bayezid Veli -tâbe serâhu- hazretlerinin vakf-ı celili müsteğıllâtından Feri Karyesi'nde Sakız Ağacı Caddesi'nde olup malumü'l-isim kesanın bâ-temessükât taht-ı tasarruflarında bulunan tarlaların mahalle şekline iğrağında lede'l-istîzân irade-i seniyye-i hazret-i hilafet-penâhî şeref sudur buyurulmuş olmasına binâen ol babdaki nizam-ı mahsus mucebince mezkur tarlalardan bin iki yüz arşınlık bir arsanın mekteb mahalli olmak üzre tefrik olunduğu Evkaf Nezaret-i celilesi Muhasebesinden alınan ilmühaberden anlaşılmış..."

Sakız Ağacı'na bir okul inşa edilmesi kararının hemen alınamadığı, bu konu hakkında geçmişte birçok tartışmaların ve itirazların olduğu görülmektedir. Yazışmalara 11 Nisan 1878'de başlanılan ve 29 Ekim 1898'de tamamlandığı belirlenen bu sürecin yer aldığı arşiv belgesi ve ekleri bazı hususların aydınlatılması bakımından kayda değerdir. Söz konusu belgede ilk olarak Evkaf Nezareti'nden gönderilen bir ilmuhaber sureti yer almaktadır. Buna göre; Feri Karyesi Sakız Ağacı Caddesi'nde bulunan ve Sultan Bayezid-i Veli vakfına gelir sağlayan toplam on altı bin ziralık tarlaların kullanım hakkı Osmanlı tebasından Andon ile Karagöz oğlu Tavukçu Konstantin ve Latin Milleti kadınlarından Françesko isimli kişilere ait olup, bin üç yüz kırk sekiz ziralık kısmı yeniden inşa edilecek yol, üç yüz zirası inşası planlanan karakol için, kalan on dört bin üç yüz elli iki ziralık kısmı ise dört adaya ayrılmak üzere terk edilmesi kararlaştırılmıştır. Aynı yerde Küçük Mehmed Ağa Vakfı'na gelir sağlayan ve kullanım hakkı isimleri belirtilen kişilere ait olan toplam altmış yedi bin zira ölçüsünde harap durumdaki bağ yerlerinden on sekiz bin sekiz yüz sekiz ziralık kısmı açılacak yollara, kırk sekiz bin yüz doksan sekiz zirası on üç adaya bölüştürülmek üzere ayrılacaktır. Ayrılan bu on üç 
adada menzil yerleri ve dükkanların inşa edilmesi düşünülmektedir. Ayrıca yollar için yapılacak harcamanın, yerlerin satılmasından gelecek paralardan karşılanması planlanmıştır. İfrazı tamamlanacak bu bölgede karakol yeri dışında, bin iki yüz arşınlık bir yerin okul inşasına tahsis edilmesi, su, kanalizasyon ve yollarla birlikte ilgili yerlere yazı yazııması da alınan kararlar arasındadır (BOA., MF.MKT., Dosya no: 366, Gömlek no: 42) .

"Evkaf-ı Hümayun Nezaret-i celilesinden gönderilen ilmuhaberin sureti.

Sultan Bayezid-i Veli -tâbe serâhu- hazretlerinin vakf-ı celîle müsteğıllâtından Feri Karyesi'nde Sakız Ağacı Caddesi'nde olup dört dönümü teba-i Devlet-i aliyyeden Andon ve dört dönümü Latin Milleti nisvânından Françesko ve bir dönümü yine Devlet-i aliyye tebasından Karagöz oğlu Tavukçu Kostantin nâm kisânın bâ-temessükât taht-ı tasarruflarında olan ve terbian on altı bin ziradan ibaret bulunan tarlalar ile evkaf-ı mülhakadan Küçük Mehmed Ağa Vakfı müsteğıllâtından kırk iki hisse itibariyle on bir hissesi Marya ve yedi hissesi Sofya ve üç hissesi Pırlanta ve on sekiz hissesi Hacador ve üç hissesi Kuyumcu Mığırdıç ve Hacador'un vefatıyla uhdesinden kalan on sekiz hisseden sekiz buçuk hissesi Viçe'ye bade'l-ferağ dokuz buçuk hissesi müteveffâ-yı merkumun sulbiye kızları teba-i Devlet-i aliyyeden Sanduka ve Serpohi uhdelerinde bulunan terbî' an altmış yedi bin altı zirâ harab bağ mahallinden vakf-ı müşârun-ileyhe merbut olan tarlaların bin üç yüz kırk sekiz ziraı müceddeden inşa olunacak tariklere ve terbî' an üç yüz zira mahalli dahi karakolhane inşa olunmak üzre bade't-terk mâadâ on dört bin üç yüz elli iki zirâ' I dört adaya ve Küçük Mehmed Ağa Vakfı merbutâtından harab bağın terbî‘ an on sekiz bin sekiz yüz sekiz zirâ mahalli küşâd olunan tariklere terk olunarak mâadâsı bulunan terbî' an kırk sekiz bin yüz doksan sekiz zirâ' I on üç adaya taksim ve her birlerinin hisseleri tefrîk ve tahdîd olunup menâzil ve dekâkîn inşâ olunmak üzre parça parça bi'l-ifrâz sunuf-ı teb 'a-i şahaneden zuhur edecek taliblerine furuhtu ve araziden yer satılmadıkça bedelinden nizamı vechle... Maliye Nezaret-i celilesinde Tahrir-i Emlak Kalemi'ne tefrik kılınan bin iki yüz arşın mekteb mahalli için maarif ve karakolhane mahalli için Zabtiye Nezaret-i celilelerine ve tesviyesi taahhüd olunan lağım ve kaldırımlari çin Şehremanet-i celilesine ve su yolları için Su Nezaret-i behiyyesine başka başka birer kıta ilmuhaberlerinin tahrir ve itası babında senedât idaresinden tanzim kılınan müzekkereye ilmuhaberleri yazıla deyü ferman buyurulmağın mucebince kayd olunup diğer ilmuhaberleri verilmekle Maarif Nezaret-i celilesine dahi işbu ilmuhaber verildi."

İlmuhaber suretinin altında 11 Nisan 1878 tarihi yer almakla birlikte bahsi geçen kararların 25 R 1294/ 9 Mayıs 1877 tarihinde alındığı anlaşılmaktadır. Belgenin takip eden ekinde ilmuhabere atıf yapılarak okul için ayrılmış bin iki yüz zira ölçüsündeki arsaya bazı taraflardan müdahaleler olduğu belirtilerek bunun önlenmesi ve arsanın hudutlarının kesin tespitini gösteren bir haritanın düzenlenmesi istenmiştir.

"...terbî̀ an altmış yedi bin altı zirâ" harab bağ mahallinin mahalle şekline vazıyla parça parça satılmasından dolayı mekteb mahalli için tefrik olunup canib-i muhasebe-i evkafdan ita kılınan 8 Rebiülevvel sene [1]295 tarihli ilmuhaber mucebince nezaret-i celilelerine terk olunan bin iki yüz zirâ" arsaya bazı tarafdan müdahale ve tecavüz olunduğu istihbâr olunup bu ise câiz olamaycağından müdahale ve tecavüz-i vâkıanın meniyle nezâret-i celîleleri arazi komisyonuna memur fütüvvetli Bedri Efendi'nin hazır olduğu halde mezukr arsanın bi'l-mesâha tayin-i hududuyla bir kıta haritanın tanzim ve irsali hususunun Altıncı Daire-i Belediye Müdüriyeti'ne işar buyurulması babında emr u ferman hazret-i men lehü'l-emrindir."

Okul için ayrılması istenen yerlerle ilgili haritanın düzenlenmesi ile birlikte yer seçimi konusunda bir hata yapıldığı anlaşılmıştır. Zira okul yapılması için işaretlenen Koranti Sokağı'nda Eftik Kadın'a ait seksen bir, seksen üç ve seksen beş numaralı arsalar biri 
okul yeri için fazla geldiğinden bunlardan sadece seksen beş numaralı arsa yeterli görülmüş, fakat bu kez söz konusu arsanın Nikolina Kadın'a ait olduğu ortaya çıktığından kendisinden yazııı izin alınması gerekmektedir.

"Maarif Nezaret-i celilesine

Devletli efendim hazretleri

Eftik kadının Feri Karyesi'nde mutasarrıfe olduğu arazinin tayin ve tahdidi zımnında vaki olan müracaatı üzerine tanzim edilen harita kopyası derdest-i ita ise de Koranti ve Edirnekapı Sokaklarıyla mahdud olan haritada Koranti Sokağı'nda seksen bir ve seksen üç ve seksen beş numaralar ile murakkam ve beheri beş yüz on zira hesabıyla ceman bin beş yüz otuz ziradan ibaret bulunan arsalar miyanında seksen beş numaralı mahallin bin iki yüz zira olarak mekteb arsası deyü kayd ve işaret olunduğu tahrir kaleminden beyan edilmiş ve mezbure ise kanunen üç bin zira mahalden mekteb mahalli tefriki lazım gelmeyeceğini ve işbu kayd tahrir yanlış olup fakat muameleleri teehhür etmemek üzre mezkur seksen beş numaralı arsaya mekteb inşa olunmak üzre nezaret-i celile-i âsifânelerine terk ve teberrua hazır bulunduğunu ifade eylemiş olmasına nazaran iktizâ-yı halin müsaraaten ifası zımnında keyfiyetin savb-ı samî-i nezaret-penâhîlerine işarı hakkında Altıncı Daire-i Belediye Müdüriyeti'nden varid olan tezkire üzerine Hendesehane'den ita kılınan müzekkire meâlinde her ne kadar daireden Eftik Kadın tahrir edilmiş ise de muayene edilen musaddak 23 Şaban sene [1]314 tarihli ilam-ı şeride ve gönderilen harita kopyasında mezkur mahallerin Nikolina Kadın uhdesinde olduğu anlaşıldığından badehu taraf-ı âlî-i asifanelerine işar olunmak üzre evvel emirde mezbure Nikolina Kadının mezkur seksen beş numaralı mahalli meccanen mekteb mahalli olarak terk edeceğine dair yedinden sened ahziyle diğer arsaların lazım gelen muamelesinin dairece icrası olunan senedin nezaret-i celilelerine gönderilmek üzre buraya irsali lüzumunun müdüriyet-i mezkureye izbarı lüzumu gösterilmiş ve celb ile tetkik edilen salifü'z-zikr ilam-ı şeri münderecatına göre mezbure Nikolina Kadın mezkur mahalleri Eftik Kadından teferruğ eylediği anlaşılıp şu hale ve mezburenin mezkur arsayı nezaret-i celilelerine terk edeceğini söylemesine göre..."

Yeni ölçümlemelere göre seksen beş numaralı arsanın okul yeri için gerekli olan bin iki yüz zirayı karşılayamamasından dolayı Nikolina Kadın'ın sahibi olduğu diğer arsaların da kendi rızasıyla alınmasına karar kılınmıştır. Görüşmelerde Nikolina Kadın'ı vekili Simonaki Efendi temsil etmektedir.

“...Mir-i muma-ileyhin ifadesine nazaran sâlifü'z-zikr mekteb mahalli muahharan Nikolina Kadın uhdesine intikal eden arsa dahilinde bulunduğu halde ol vakit her nasılsa harita-i esasiyeye işaret edilmediği ve mezburenin bu kere haric ez-nizâm beş yüz küsur zirâ' mekteb mahalli terkine muvâfakat ile izhar-ı cemile eylemesi kusur yedi yüz zirâ' mahalli ketm ve ihfa maksadına müstenid ise de daire-i mezkureye mîr-i mûmâ-ileyhin be-tekrar azimetinde bu işi takib etmekde olan mezburenin vekili Simonaki Efendi hazır olduğu halde ber-muceb-i ilmuhaber bin iki yüz zirâ' mekteb mahalli Nikolina Kadın uhdesinde bulunan seksen beş ve yetmiş altı numaralı arsalar ve ittisâlinde bulunan diğer arsadan mekteb mahalli olarak terki kararlaştırılmış ve ol vechle işaret olunmak üzre celb edilen harita dahi leffen takdim kılınmış olduğundan ol vechle icrâ-yı icâbı daire-i mezkureye bildirilmek üzre cevâben işarı vâbeste-i rey-i âlî idiği beyanıyla meclise takdim kılındı."

Okul inşa etmek amacıyla ayrılan ve sahibinin rızası alınan yerin haritada işaretlenmesi ile birlikte düzenlenen çapın Hendeshane'ye gönderildiği anlaşılmaktadır.

“...Altıncı Daire-i Belediye Müdüriyetine işar-ı keyfiyet edilmesi ve mezkur mekteb arsasının sened-i hâkânîsi alınmak üzre tanzim ettirilerek bir kıta çapının isrâsı işar 
buyurulmuş ve lede't-tebliğ zikr olunan mekteb mahalli Koranti Sokağı'ndan seksen beş numaralı beş yüz on ve Edirnekapı Sokağı'ndan yetmiş altı numaralı kezâlik beş yüz on ve Eczacı Sokağı'nda üç numaralı arsadan müfrez olarak yüz seksen zira ki min haysi'l-mecmu' bin iki yüz ziradan ibaret olup Hendesehane'ye tanzim kılınan çapın gönderildiği ve bir gûne muamele yapılmaması dahi vukuat kalemine tebliğ olunduğu beyan ve izbar ve mezkur çap bi'l-havale emanet ifadesiyle leffen takdim ve tisyar kılınmağın ber-vech-i arz ve işar badehu muamele-i mukteziye-i ferağiyenin icra ve inba buyurulması babında emr u ferman hazret-i men lehü'l-emrindir."

$\mathrm{Bu}$ arada okul için ayrılmış yerle ilgili tartışmalar sürmektedir. Zira söz konusu yer Terkos Su Şirketi'nin su havuzu ile makinesi arasındaki bölgede kalmaktadır ve arsanın sahibi Nikolina Kadı'nın diğer arsalarına göre daha kıymetlidir. Sakız Ağacı mezarlığının yanında bulunan bir diğer arsanın okul inşası için kullanılması durumunda bu bölgede Bahriye Nezareti'nin baruthanesinin bulunmasından dolayı uygun görülemeyeceği belirtilmiştir. Nikolina Kadın'ın vekili Simonaki Efendi ise ifraz edilen arsanın okul inşası için yetersiz bulunması halinde diğer arsalardan birinin de verilebileceğini tekrar ifade etmiştir. Birbirini tekrar eden belgelerden bundan sonra okul için arsa arayışlarının sona erdiği ve üzerinde mutabık kalınan yerde okulun inşa edilmesinin kararlaştırıldığı anlaşılmakla birlikte bahsi geçen okulun inşasının gerçekleşip gerçekleşmediği tam olarak tespit edilememiştir.

“...Nikolina Kadın'ın Sakız Ağacı mezarlığı civarında dört bin yedi yüz yetmiş bir ve Koranti ve Kır Sokağı'nda dört bin yüz zira terbî‘ inde arsası mevcud olduğu ve mekteb mahalli ise Terkos Kumpanyası'nın su havuzuyla makinası arasında ve Koranti ve Kir Sokaklarında olan ve Sakız Ağacı Mezarlığı yanındaki arsadan daha ziyade kıymeti olup Feri Köyü'ne dahi kurbiyeyti bulunan arsanın mümtaz mahallinden ifraz edildiği ve Sakız Ağacı kabristanının civarındaki araziden mekteb mahalli ifraz edilecek olur ise mahall-i mezkurda Bahriye Nezaret-i celilesinin Baruthanesi olduğu cihetle ebniye inşasına müsaade olunmayıp nezaret-i müşarun-ileyhaca istimlakine kıyam olunmakda olduğu beyan olunmasına ve ifraz edilen arsa mektebe elverişli görülmediği suretde taleb edilen cihetden mekteb mahallinin itasına muvafakat edeceğini merkumenin vekili Simonaki Efendi be-tekrar ifade eylemesine binâen mersul harita mucebince ifraz edilen mahallin mekteb olarak nezaret-i celile namına ahzi tensib buyurulduğu takdirde muamele-i mukteziye-i..."

Başlangıçta da belirtildiği gibi Feriköy'de bir okul inşası ile ilgili olarak 9 Mayıs 1877 tarihinde karar alınmış, ancak ilk belirlenen yerin seçimi konusunda yapılan hatanın düzeltilmesi amacıyla yapılan görüşmeler sürecin uzamasına yol açmıştır. Bu bağlamda belgenin eklerinde en son tespit edilen tarih 29 Ekim 1898 olup, bir okul inşası ile ilgili karar aşamasının on iki yıl sürmesi çok da olağan kabul edilebilecek bir süre değildir. Ayrıca yazışmalardaki en son tarih olan 1898 yılından sonraki süreç de bilinmemektedir. Söz konusu belge, merkezi otoritenin Feriköy'de Sultan Bayezid-i Veli vakfına ait yerlerin mahalle haline dönüştürülmesi kararını da içermesi bakımından dikkat çekicidir. Bölgede vakıf yerlerinin kullanım haklarının Eftik Kadın, Nikolina Kadın gibi Osmanlı tebasından gayri müslimlere daha önceki bir tarihte verilmiş olduğunun tespit edilmesi Osmanlı'da özel mülkiyete geçiş ve semtin tarihi hakkında bilgi sahibi olmamızı sağlamıştır.

\section{DEĞERLENDİRME VE SONUÇ}

19. yüzyılın sonlarına doğru sosyal, siyasi ve ekonomik alanda meydana gelen gelişmeler Osmanlı'nın başkenti İstanbul'un fetihten bu yana gayri müslimlerin yoğun olarak yaşadığı bilinen Beyoğlu bölgesi ve çevresinde etkisini hissetirmiştir. Bu 
etkileşimin bazı önemli sonuçları olmuştur. Özellikle bir yandan yüzyılın sonlarına doğru toprak rejiminde yapılan düzenlemelerle birlikte yabancılara mülk edinme hakkının tanınması, diğer yandan kaybedilen topraklardan göçen Türklerin yerleşim sorunları merkezi idarenin nüfus ve iskan politikalarında bazı düzenlemelerin yapılmasına yol açmıştır. İmparatorluğun kuruluşundan itibaren sosyal refahın sağlanmasında büyük katkıları olmuş vakıflara ait mülklerin dönüştürülerek özel mülkiyete açılması bu düzenlemelerden biri olarak sayılabilir. Niteliği itibariyle şahıs vakıflarının dönüştürülmesi mümkün olmadığından sultan vakıflarına ait arazilerin (gayrısahih vakıf arazi) bu amaçla kullanıldığı düşünülmektedir. Bu bağlamda bugüne kadar hakkında çok fazla araştırmaya konu edilmemiş Feriköy semti arşiv belgeleri yardımıyla incelenmiştir. Belgelerden elde edilen tespitler; Feriköy Semti'nde Sultan Bayezid-i Veli vakfına ait arazilerin yukarıda belirtilen nedenlerden dolayı zaman içerisinde dönüştürülerek yeni bir ikamet alanı oluşturulduğunu doğrulamaktadır.

\section{KAYNAKLAR}

Dünden Bugüne İstanbul Ansiklopedisi (D.B.I.A.), C:3, Kültür Bakanlığı ve Tarih Vakfı'nın Ortak Yayını, İstanbul, 1994.

Ekinci, Ekrem Buğra, Osmanlı Hukuku Adalet ve Mülk, Arı Sanat Yayınları, İstanbul, 2008

İstanbul Ansiklopedisi, Reşad Ekrem Koçu, C: 10, Koçu Yayınları, İstanbul, 1971.

Kenanoğlu, Mustafa Macit, "1858 Arazi Kanunnamesinin Osmanlı Siyasal ve Toplumsal Yapısı Üzerindeki Etkileri (1858-1876)", Doktora Tezi, Ankara Üniversitesi Sosyal Bilimler Enstitüsü Kamu Yönetimi ve Siyaset Bilimi Anabilim Dalı, Ankara, 2002.

Kostandov, Georgi P., İstanbullu Bulgarlar ve Eski İstanbul Geçmişten Günümüze Osmanlı Bakiyesi Bulgarlar Üzerine Bir Araştırma 1800-2000, Sanat Dükkanı Yayıncılık, İstanbul, 2011.

Mundy, Martha, Richard Saumarez Smith, Modern Devlet'e Giden Yolda Mülk Siyaseti: Osmanlı Suriyesi'nde Hukuk Yönetim ve Üretim, Çev: Süleyman Kızıltoprak, Tarih Vakfı Yurt Yayınları, İstanbul, 2013.

Onar, Sıddık Sami, Tanzimat'tan Cumhuriyet'e Türkiye Ansiklopedisi, C:3, İletişim Yayınları, İstanbul, 1985.

Pervititch, Jacques, Sigorta Haritalarında İstanbul, Proje Koordinatörleri: Seden Ersoy, Çağatay Anadol, Tarih Vakfı, İstanbul.

Şişli Rehberi (Ş.R.), Şişli Belediyesi, İstanbul, 1987.

Tuncer, Hadiye, Osmanlı İmparatorluğu'nda Toprak Hukuku, Arazi Kanunları ve Kanun Açıklamaları, Tarım Bakanlığı Mesleki Mevzuat Serisi, Ankara, 1962.

\section{Başbakanlık Osmanlı Arşivi (BOA.) Belgeleri}

BEO., Bab-ı Ali Evrak Odası

DH.ID., Dahiliye İdari Kısım Belgeleri

DH.MKT., Dahiliye Nezareti Mektubi Kalemi

MF.MKT., Maarif Nezareti Mektubi Kalemi 